\title{
Redesign and upcycling - a solution for the competitiveness of small and medium-sized enterprises in the clothing industry
}

SUNHILDE CUC

DOI: 10.35530/IT.069.01.1417

SIMONA TRIPA

\section{REZUMAT - ABSTRACT}

\section{Reproiectare și reciclare - o soluție pentru competitivitatea întreprinderilor mici și mijlocii din industria de îmbrăcăminte}

\begin{abstract}
Lucrarea urmărește deschiderea unui nou domeniu de cercetare aplicabil întreprinderilor mici și mijlocii din industria de îmbrăcăminte, și anume, accentul pe designul noului produs prin creșterea eficienței utilizării și reciclării țesăturilor și o perspectivă asupra lanțului de valori care se concentrează pe etapa anterioara în cadrul acestuia. Obiectivul principal al lucrării este de a prezenta modul în care întreprinderile mici și mijlocii (IMM-urile) din industria de îmbrăcăminte pot obține un avantaj competitiv prin utilizarea unei abordări durabile. Acest studiu oferă soluții utile pentru înțelegerea proceselor de dezvoltare a produselor pentru industria modei cu scopul de a regândi, reutiliza sau recicla deșeurile în stadiul de producție. Se propune o noua conexiune între diferitele componente ale lanțului valoric: design, producție, marketing pentru a crea articole de modă, astfel încât, atunci când este posibil, aceste deșeuri să fie utilizate pentru a crea noi produse și se subliniază avantajele implementării acestei soluții. Producția durabilă poate fi o modalitate de a obține un avantaj competitiv. Această strategie poate avea succes prin integrarea lanțului valoric vertical, prin consolidarea departamentului de creație, a designului vestimentar și prin implicarea în marketing și vânzări. În industria de îmbrăcăminte, strategia de integrare a designului și vânzarea cu amănuntul pot duce la un proces de proiectare mai flexibil și, prin urmare, la o performanță ridicată a produsului.
\end{abstract}

Cuvinte-cheie: competitivitate, îmbrăcăminte, IMM-uri, sustenabilitate, reciclare

\section{Redesign and upcycling - a solution for the competitiveness of small and medium-sized enterprises in the clothing industry}

The paper aims to open a new field of research applicable to small and medium enterprises in the clothing industry, namely, the focus on new product design by increasing the efficiency of fabric use and recycling and a value chain perspective that concentrates on downstream in the chain. The main objective of this paper is to present how small and medium-sized enterprises (SMEs) in the clothing industry can achieve a competitive advantage by using a sustainable approach. This study provides useful solutions for understanding the product development processes for fashion to rethink, reuse or upcycle the waste in the production stage. We propose a better connection between different links of the value chain: design, production, marketing to create fashion items so when possible, this waste to be used to make new products and highlights the advantages of implementing this solution. Sustainable production can be a way of gaining a competitive advantage. This strategy can be successful by integrating the vertical value chain by strengthening the creative department, fashion design, and involvement in marketing and sales. In the clothing industry, the strategy of integrating design and retail can lead to a more flexible design process and, therefore, to an increased product performance.

Keywords: competitiveness, clothing, SMEs, sustainability, upcycling

\section{INTRODUCTION}

The textile and clothing sector in Romania is one of the key industrial sectors. The sector accounts for providing employment to a large of labor force in the country. It creates employment for 137000 employees and it contributes for about $11 \%$ of the Romanian's export revenues, at the second place after automotive industry, who held $40 \%$. Despite being rated among the top European exporters of textiles, over the past years, the Romanian textile and clothing industry has become less competitive in the global marketplace [1]. There are many reasons for this, including the liberalizing policies of the EU and WTO, the low profitability as well as the intense competition from low cost producing countries.

Romania's competitive advantage in clothing industry, reported to the European one, is mainly due to low-cost labour force. The clothing industry is considered to be one of the most labour intensive industry that focuses on creating, designing, manufacturing, marketing, consuming, supplying chain, trading and many other components of clothing, and its accessories as a whole. Considering this, labour costs have a major impact of the competitiveness in this market and their continued growth has negatively influenced Romanian competitiveness. Due to the concurrent factors impacting the clothing industry, Romanian producers can no longer compete based on cost alone.

Managers of the companies in clothing industries face major challenges to deal with the frequent problems that arise from ever changing operating conditions. They also have faced sophisticated strategic challenges that have to be addressed successfully if 
the firm will survive [2]. Under pressure of various unfavorable conjectural factors, Romanian clothing industry has traveled a restructuring period forced by the defensive adaptation type and characterized by reducing the market share and attempting to increase the productivity.

Clothing companies with strong domestic production, like Romanians, will need to rethink their strategies to focus on high value added activities, taking into account and embracing the new paradigm of circular economy and decreasing the production losses to be capable of improving their industrial competitiveness with trade balance and increase in productivity. Products with high added value can be achieved using advanced technologies or in the fashion sector through increased creativity and design that incorporate efficiently methods so as to minimize waste.

\section{The objectives of the study}

To address the purpose of the study and examine how small and medium-sized enterprises (SMEs) in the clothing industry can achieve a competitive advantage, the following objectives are proposed:

1. Analyze theoretical backgrounds and meanings of sustainability, competitiveness and competitive advantage.

2. Examine how clothing industry is affected by the ecological issues.

3. Examine how redesign and recycle can be a solution for the competitiveness of small and mediumsized enterprises (SMEs).

\section{Findings}

1. Sustainable production can be a way of gaining a competitive advantage. This strategy can be successful by integrating the vertical value chain by strengthening the creative department, fashion design, and involvement in marketing and sales.

2. In the clothing industry, the strategy of integrating design and retail can lead to a more flexible design process and therefore, in an increased product performance.

\section{Originality/value}

The paper opens a new field of research aplicable to small and medium enterprises in the clothing industry, namely, the focus on new product design by increasing the efficiency of fabric use and recycling and forming a value chain perspective that concentrates on downstream in the chain.

\section{THEORETICAL BACKGROUND:} COMPETITIVENESS, COMPETITIVE ADVANTAGE AND SUSTAINABILITY

Competitiveness can be assessed at different levels of aggregation: firm, industry, and country. Firm level analysis focuses on behaviours and performance of firms: using profitability, costs, productivity and market share as indicators of competitiveness

The literature on competitiveness indicates that the most feasible response is to 'upgrade' - to make better products, to produce them more efficiently or move into more skilled activities [3]. According to Porter (1990), competitiveness can be measured on the basis of productivity. Today, beyond financial or market-based indicators, performance should be measured in terms of how an organization manages its critical success factors like innovativeness, quality, ethical and ecological standing, social responsibility [4-6].

According to the generally established view of competitive process, a firm's performance is influenced by its competitive advantages. In its turn, the nature of such advantage results in one or more specific sources of competitive advantage which a firm controls. Concept of competitive advantage has a long tradition in the strategic management literature. Competitive advantage is a set of unique features of a company and its products that are perceived by the target market as significant and superior to the competition. Porter (1985) states that there are, in general, only two possible competitive advantages a firm may possess, a cost advantage or a differentiation advantage [7]. However, positive competitive outcomes can only be obtained by matching competitive strategy to available resources: for example, exceptional creative or scientific talent is useful for innovative differentiation, and economical production cost structures are needed to support sustained cost leadership [8].

In gaining competitive advantage, companies must develop new resources, capabilities, and activities because of the scarcity of natural resources [9]. Sustainability is not only instituting pollution controls or recycling programs when manufacturing products but it is about minimizing the harmful impact of the manufacturing processes on the environment at every stage, and it also brings new challenges to the companies, being a source of creativity and innovation.

Sustainability, as a business process, is the basis for low cost business strategies that include efficiency in every aspect of the planning process [10]. Ecological sustainability focuses on profitability through environmentally friendly operating processes. These processes may constitute a key basis for competitive advantage in the near future.

Managers begin to realize the fact that a large number of consumers prefer eco-friendly offerings, and that their businesses can score over rivals by being the first to redesign existing products or create new ones. To completely assume ecological production and its benefits, a company should adopt environmentally friendly policies and practices in the entire supply chain. In the design phase, it should use more eco-friendly products, planning for reuse and recycling: "Products, processes, and systems should be designed for performance in a commercial afterlife [11]. The manufacturing process needs to be more efficient, planning for optimum use of material and for reduction in waste production.

The literature has acknowledged the value of ecological sustainability and the internal capability of firms 
for its success. Several studies have been conducted in the past to investigate the impact of sustainable production on the overall organizational performance, financial rewards and competitiveness [12-13]. The nature of competition has changed due to the search for sustainability. Therefore, companies that are aware of this changing environment and set the sustainability as their mission will enjoy the advantages of first movers [14]. Practicing environmental sustainability encourages companies to look for new processes, technologies and introduce new products in order to overcome the challenges.

\section{ECOLOGICAL ISSUES IN THE CLOTHING INDUSTRY}

Growing competition in the clothing industry has forced companies to have serious attention towards the sustainability concept. For apparel manufacturers, involving in a sustainable production, finding and nurturing a competitive advantage through this can mean not only survival but also increased profit that can be successful in the long term.

In recent years, industrial development has achieved environmental improvements and has moved towards a smaller environmental impact. However, at the same time, production as well as consumption has increased by the same levels, which erodes the environmental benefits of the technological advances, i.e. the rebound effect [15].

Eco-materials and eco-efficiency have been top subjects that concern the textile industry in recent years. The strategy to waste management must give priority in the first place the prevention, in the second place recycling, reusing and revalorization and finally dispose waste. The clothing industry needs to find imaginative solutions to produce environmental improvements. The increasing amount of textile and clothing waste has led to the necessity of development of methods using the textile waste, i.e. reuse, recycling or redesign [16].

McDonough and Braungart, creators of the cradle to cradle concept, have advocated radical design innovations for perpetually circular material reuse [17-18]. Upcycling is one of the most sustainable circular solutions in the waste hierarchy, positioned between reuse and recycling, since upcycling typically requires little energy input and can eliminate the need for a new product [19]. Moreover, at the beginning of the $21^{\text {st }}$ century, several designers have made use of the concept of reuse and redesign in designing trendy products.

Reuse and recycling of materials, such as old clothes, manufacturing scraps and unsold items can be the material of sustainable fashion [20]. In contrast to reusing or recycling, upcycling uses available fabrics, clothes or other items to improve upon the original ones.

McDonough and Braungart offers a broad definition claiming that upcycling is "optimizing the materials, ingredients, and process pathways in such a way that waste is converted to raw materials for nature or some other industry" [21].

Murray (2002) [22] describes it as "not merely conserving the resources that went into the production of particular materials, but adding to the value embodied in them by the application of knowledge in the course of their recirculation. So, if one can add value - economic, intellectual, emotional, material - to a product through the process of reuse, it can be called 'upcycled" [23].

\section{AN UPCYCLING SOLUTION FOR THE MASS PRODUCTION}

Given the specificity of the products of clothing, usually upcycling in design and production has mostly been applied to unique products or for very small series by tailors or by small-scale fashion textile companies. Our aim is to apply upcycling in mass production more widely and find solutions for companies interested in finding a more environmentally sustainable solution to their textile waste problems. In order to implement the upcycling method, it is important to have an overview of the textile waste available because this is what dictates the item of clothing that can be created. By and large, textile waste can be divided into three groups: pre-consumer waste, production waste and post-consumer waste. All these types of textile waste can be used in fashion design. Each, however, requires a different technique when used as an input material

In this case, more approaches can be distinguished: the textile waste is used by the company that produces it (as production waste or pre-consumer waste) or the input material is obtained from other manufacturers.

For our example, we use the production waste because the input material for the production process is scraps from the apparel industry, which are generally small-sized, meaning that up to $25 \%$ of the material (depending on fabric design or proposed model) is wasted. Among the various processes of clothing production, cutting is the major area where fabric waste is generated. Proper investigation of the fabric losses during the cutting process can help the management to minimize material wastage. During the cutting process, two types of fabric losses occur, namely, marking loss and spreading loss. The marking loss arises due to the gap and the non-usable areas at places between the pattern pieces of a marker. Marker efficiency indicates the amount of marking loss. Spreading loss is the fabric loss outside the marker. The various fabric losses outside the marker can be broadly classified into different groups, namely ends of ply losses, ends of piece losses, edge losses, splicing losses, remnant losses, ticket length losses, etc. [24]. The waste is within the company so they don't have to be transported, stored, etc., the cutting efficiency is high because the material is placed in the batch and for their processing is not necessary additional investments. 


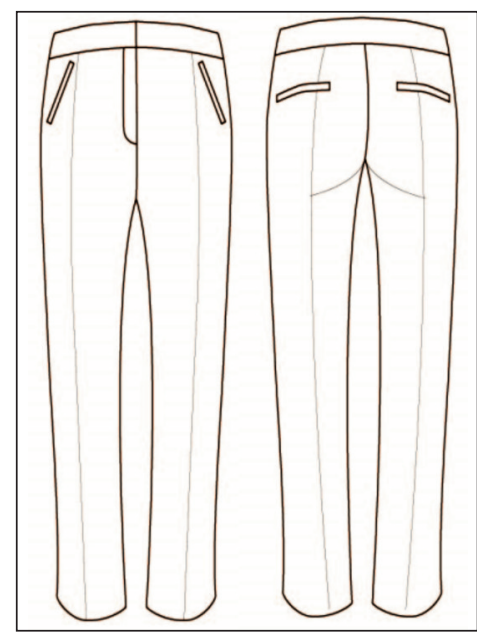

Fig. 1. Modell1. Men trousers (fabric: corduroy)

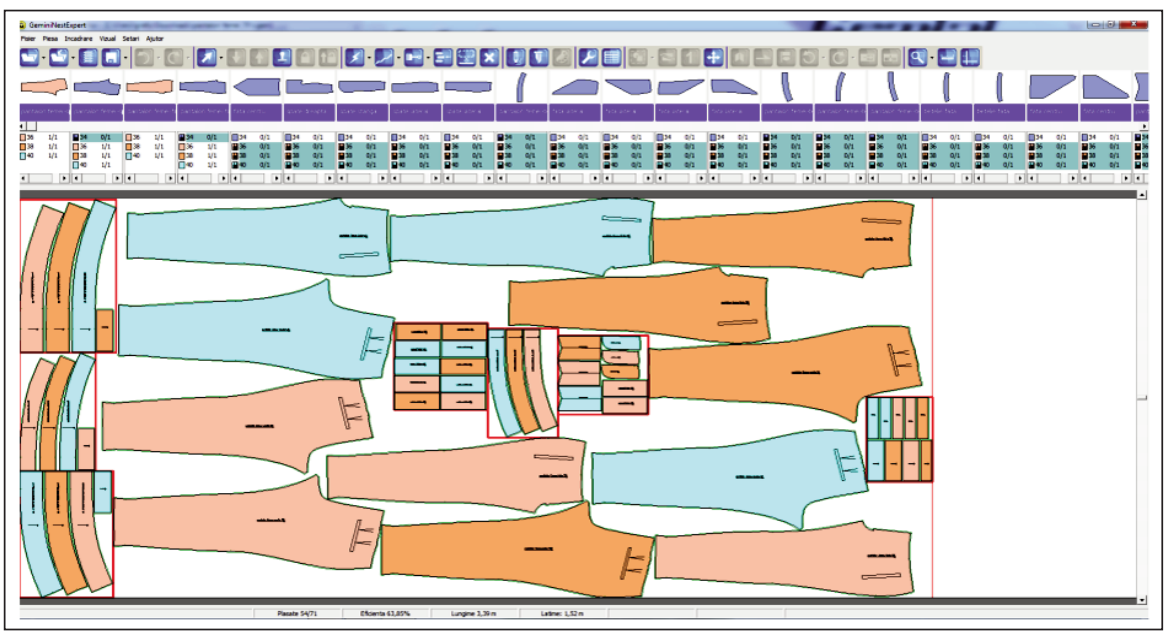

Fig. 2. The marker of the men trousers for 36,38 and 40 size
For the purpose of our paper, we prefer to present a solution to a real problem proposed by a company in Bihor County. The order which the company from Oradea has received was a lot of production of men's pants made of corduroy (model of figure 1), for which cutting efficiency accepted by the beneficiary was $60 \%$.

In order to solve the problem, we adopted two sets of measures: The first step we used was to minimize the fabric wastage so as to prepare the most efficient marker. The marker efficiency is usually influenced by the fabric characteristics (differences in face and back, lengthwise directionality, crosswise symmetry, need for matching the fabric design, length of design repeat, and fabric width); shapes of pattern pieces, fabric utilization standards and marker quality [25].

Efficiency of marker depends on how tightly the pattern pieces are fit together in the marker. Here, total surface area of the pattern pieces is compared to the total area of the marker for calculating the percentage of fabric that is used.

Marker efficiency is usually influenced by fabric characteristics (differences in face and back, lengthwise directionality, crosswise symmetry, need for matching the fabric design, length of design repeat, and fabric width); shapes of pattern pieces, fabric utilization standards and marker quality.

At first, with the help by the CAD system Gemini Nest Expert software, pattern for 36,38 and 40 size has been made. The marker width is $1,520 \mathrm{~m}$ and marker length is $3,383 \mathrm{~m}$. To increase the fabric utilization percentage we use three garment sizes in the same marker and include in the marker both large and small pieces. Smaller pieces can often be nested with larger pieces. Grain line markings determine the placement of the pattern relative to the warp yarns in woven or wales in knit fabrics. Pattern for different parts of the 36,38 and 40 size of the corduroy trousers has been shown in figure 2. The area of each pattern piece is determined by the computer. The area in between the pattern pieces, which is not used by garment parts, is waste.
Because of the above-mentioned restrictions, even if we provided a combined framing of several small sizes $36,38,40$, we could not get a higher efficiency of $63.85 \%$, which are within the limits imposed by the customer $(60 \%)$, but is unsatisfactory in terms of the high amount of waste.

Further, to use the remains fabric that covers the area in between the trousers pattern pieces, we have created a new product, a skirt design (figure 3), that diminishes and upcycled the production waste results in the production of corduroy trousers. For to reduce $\%$ waste, which in this case would be $36.15 \%$, we made a new marker in which we put in the same area the parts of skirt - size 34 - skirt made of many small parts - figure 3 .

By introducing a new product in the presented marker, we managed to increase the marker efficiency from $63.85 \%$ to $75.64 \%$. Moreover, after marketing the new product, the economic efficiency of the firm increases. As the fabric is the major raw material in a garment, the saving of very little amount of fabric per garment or reuse is efficient and it can also save money, which can increase the profit of the company substantially.

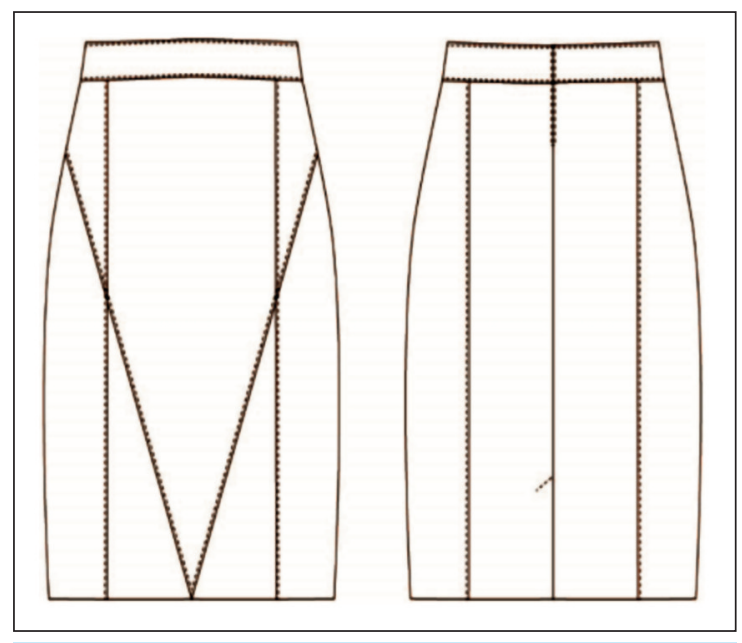

Fig. 3. Modell 2. Skirt (fabric: corduroy) 


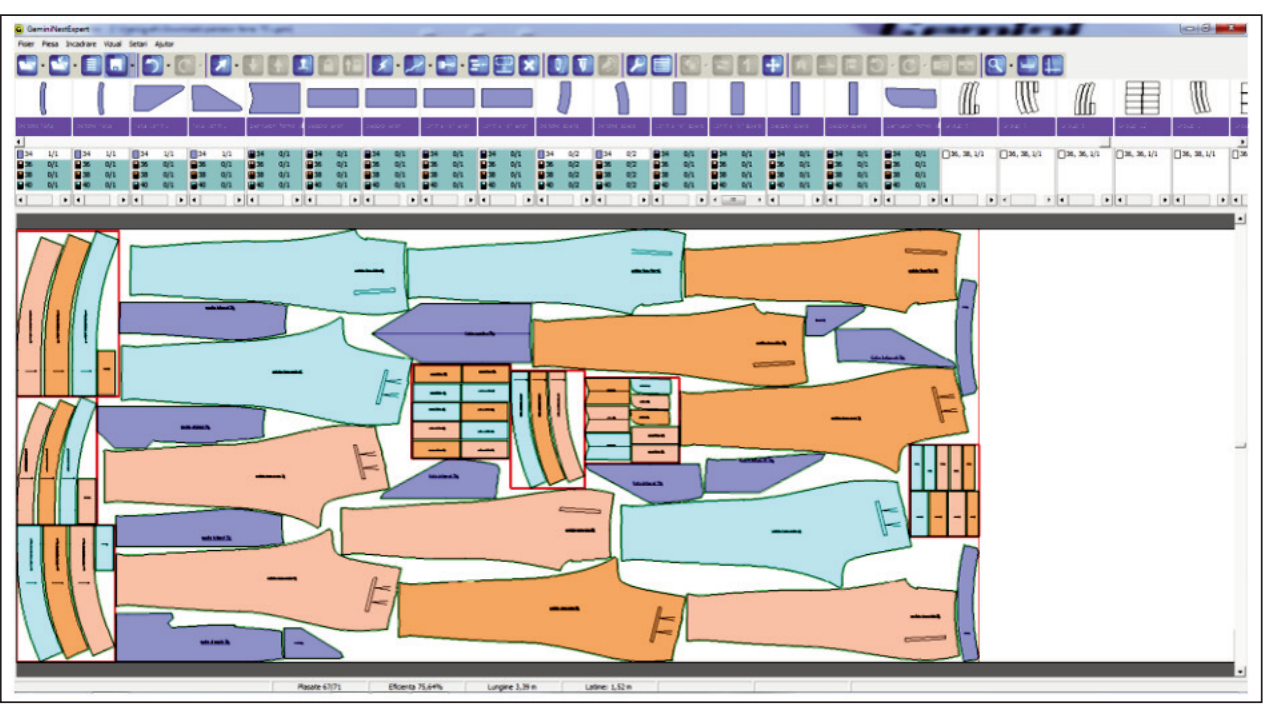

Fig. 4. The marker of the men trousers for 36,38 and 40 size and skirt for 34 size
- They have to pursue the market and promote their own products through a marketing policy that attract eco-sensitive customers.

Among the benefits of applying this solution there is one that stands out - reducing the wastes resulting from the cutting operation and the development of competitive products. This is a result of the fact that the raw materials incorporated in these comes from If in the free spaces that remained after fitting the parts from initial order (trousers in our case) not all the parts of the skirt can be fitted (as shown in the figure 4) they may be placed on another marker that will serve for cutting the parts of some products made of the same material or another one compatible with the first thus obtaining an increase of fitting efficiency.

\section{CONCLUSION}

This study provides useful solutions for understanding the product development processes for fashion to rethink, reuse or upcycled the waste in the productions stage.

Reduction of the waste and the making the new products does not require too much effort and expenditure. However, it is necessary that small and medium enterprises should consider the following:

- They must be concerned about modernization and purchasing suitable software,

- They have to encourage the creative activity by employing fashion designers who are able to create new models and make different combinations of materials, the waste - for which the company does not have to pay.

Moreover, the company will reduce waste management costs which can be reflected in the sale price of the company products or in the company profit. Other benefits could result from the company's image who can promote eco-friendly products and thus they can win additional market shares - knowing that today more and more buyers are sensitive to environmental issues.

Starting or shifting to this new business offers a potential economic benefit of upcycling. Alongside the economic benefits, managers have to realise the importance of the effective implementation of environmental strategies as a critical factor for becoming competitive in the global market in the future. The companies can create and propose more imaginative, courageous fashion using sustainable materials. Sustainable production can be a way of gaining a competitive advantage. In the clothing industry, the strategy of integrating design and retail can lead to a more flexible design process and, therefore, in an increased product performance.

\section{BIBLIOGRAPHY}

[1] Tripa, S., Cuc, S., \& Oana, I. (2016). Revealed comparative advantage and competitiveness in Romanian Textile and Clothing Industry/Avantaj comparativ aparent si competitivitate în industria de textile si de confectii din România., In: Industria Textila, 2016, 67(5), p. 338.

[2] Girneata, A., Giurgiu, A., Dobrin, O. C., Popa, I., Popescu, D. I., Cuc, S., \& Voicu, L. (2015). Performance management practices in Romanian textile and clothing companies/Practici de management al performantei în companiile românesti de textile si confectii., In: Industria Textila, 2015, 66(2), p. 108.

[3] Kaplinsky, R. (2000). Globalisation and unequalisation: What can be learned from value chain analysis?. In: Journal of development studies, 37(2), pp. 117-146.

[4] Porter M. E. (1990), The competitive advantage of nations, Harvard Business Review, 68(2), pp. $73-93$.

[5] Boynton, A. C., \& Zmud, R. W. (1984). An assessment of critical success factors. In: Sloan management review, 25(4), pp. 17-27.

[6] Depperu, D., \& Cerrato, D. (2005). Analyzing international competitiveness at the firm level: concepts and measures. In: Quaderni del Dipartimento di Scienze Economiche e Sociali, Università Cattolica del Sacro Cuore Piacenza, 32, 2007-2013. Available online http://dipartimenti.unicatt.it/dises-wp_azzurra_05_32.pdf 
[7] Porter, M.E. (1998). Competitive advantage: creating and sustaining superior performance: with a new introduction. The Free Press, New York.

[8] Barney, J. (1991). Firm resources and sustained competitive advantage. In: Journal of management,17(1), pp. 99-120.

[9] Rodriguez, M.A., Ricart, J.E. \& Sanchez, P. (2002). Sustainable development and the sustainability of competitive advantage: A dynamic and sustainable view of the firm. In: Creativity \& Innovation Management, 11 (3), pp. 135-146.

[10] Stankevičiūtè, E., Grunda, R., \& Bartkus, E. V. (2012). Pursuing a cost leadership strategy and business sustainability objectives: Walmart case study. In: Economics \& Management, 17(3), 1200-1206. Available online http://doi.org/10.5755/j01.em.17.3.2143

[11] Anastas, P. L. \& Zimmerman, J. B. Through the 12 principles of green engineering. In: Environmental Science and Technology, 2003, March 1, pp. 95-101A.

[12] Kurapatskie, B., Darnall, N., Which corporate sustainability activities are associated with greater financial payoffs?, In: Business strategy and the environment, vol. 22, no. 1, pp. 49-61, 2012.

[13] Cuc, S., lordanescu, M., Gîrneata, A., \& Irinel, M. (2015). Environmental and socioeconomic sustainability through textile recycling/Sustenabilitatea de mediu si socioeconomica prin reciclarea textilelor. In: Industria Textila, 66(3), p. 156.

[14] Nidumolu, R., Prahalad, C.K. \& Rangaswami, M.R. (2009). Why sustainability is now the key driver of innovation. In: Harvard Business Review, 87 (9), pp. 56-64.

[15] Throne-Holst, H., Stø, E., \& Strandbakken, P. (2007). The role of consumption and consumers in zero emission strategies. In: Journal of cleaner production, 15(13), pp. 1328-1336.

[16] Dissanayake, G., \& Sinha, P. (2015). An examination of the product development process for fashion remanufacturing. In: Resources, Conservation and Recycling, 104, pp. 94-102.

[17] Braungart, M. \& McDonough, W., 2002. Cradle to cradle. Remaking the way we make things. Vintage, New York.

[18] McDonough, W. \& Braungart, M., 2013. The upcycle: Beyond sustainability - Desining for abundance. North Point Press, New York:

[19] Szaky, T., 2014. Outsmart waste. San Francisco, CA: Berrett-Koehler Publisher, Inc.

[20] Fletcher, K. Sustainable fashion and textiles, In: Design Journeys, Earthscan: London, UK, 2008.

[21] McDonough, W. \& Braungart, M. (2013). The upcycle: Beyond sustainability-designing for abundance. New York, New York: North Point Press.

[22] Murray, R. (2002). Zero waste. London, UK: Greenpeace Environmental Trust. Available online http://www. zerowasteeurope.eu/wp-content/uploads/2011/04/zero-waste-by-robin-murray.pdf

[23] https://library.ndsu.edu/repository/bitstream/handle/10365/23189/Meyers_Designing $\% 20$ and $\% 20$ Selling $\% 20$ Recycled\%20Fashion.pdf?sequence=1

[24] Pamuk, O., \& Yildiz, E. Z. (2016). A study about parameters affecting the marker plan efficiency. In: Journal of Textile \& Apparel/Tekstil ve Konfeksiyon, 26(4).

[25] Dumishllari, E., Guxho, G.,( 2015), Impact of marker on cut plan in garment production, In: International Journal of Innovative Research in Science, Engineering and Technology, vol. 4, I. 8, pp. 7377-7381.

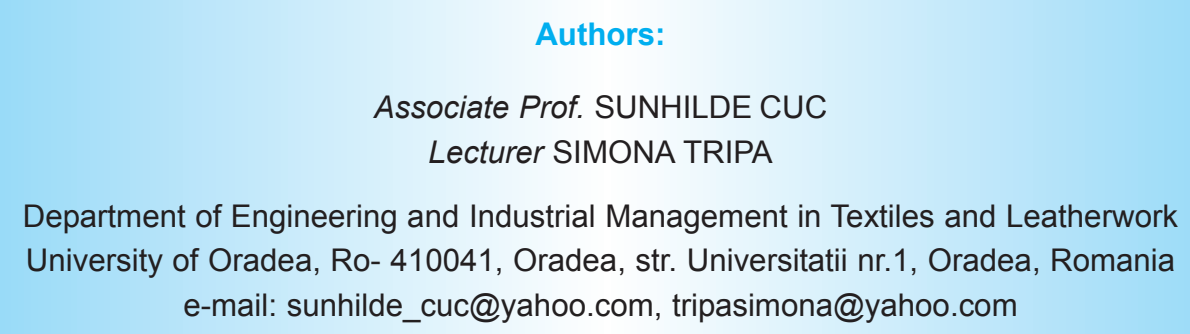

Corresponding author:

SIMONA TRIPA

e-mail: tripasimona@yahoo.com 